\title{
Effect of Botanical Extracts: A Potential Biocontrol Agent for Xanthomonas Oryzae Pv. Oryzae, Causing Bacterial LeafBlight Disease of Rice
}

\author{
Syed Atif Hasan Naqvi ${ }^{1 *}$, Ummad-ud-Din Umar ${ }^{1}$, Ammarah Hasnain ${ }^{2}$, Ateeq ur Rehman ${ }^{1}$ and Rashida \\ Perveen $^{1}$
}

${ }^{1}$ Department of Plant Pathology, Bahauddin Zakariya University, Multan, Pakistan, ${ }^{2}$ Biological Science Department, Forman Christian College University, Lahore, Pakistan.

Abstract | Bacterial leaf blight is a devastating disease of paddy rice crop throughout the rice growing countries. Several commonly available plant decoctions were investigated as the bioactive eco-friendly compounds, and as the possible alternatives to hazardous chemicals for the control of BLB of rice. Aqueous extracts of fifteen different plant parts either individually or in combination were tested at various concentrations under in vitro conditions by poison food and disk diffusion techniques while best effective seven were trialed in glass house and field experiments to determine their efficacy against Xanthomonas oryzae pv. oryzae. In vitro and in vivo studies under different conditions showed significant response of Mentha piperita, Azadirachta indica and Aloe vera either tested individually or in combination of two or more than two decoctions against the bacterium in question. When used individually, $M$. piperita demonstrated best in vitro, field and glass house experiments followed by the $A$. indica which also proved its efficacy against the pathogen. The combination of $M$. piperita, A. indica and $C$. limon was superior in reducing the BLB of rice. Besides this, all treatments showed significant effect on the agronomic traits of rice plants. The reduction of disease in all the trials along with healthy crop stand in glass house and field indicated that these decoctions might play an important role in biological management strategies for the control of BLB of rice. The present research may provide an avenue for the formulation of new bactericides for future uses.

Received | November 26, 2018; Accepted | November 30, 2018; Published | December 13, 2018

*Correspondence | Syed Atif Hasan Naqvi, Department of Plant Pathology, Bahauddin Zakariya University, Multan, Pakistan; Email: atifhasanshah@hotmail.com

Citation | Naqvi, S.A.H., U.D. Umar, A. Hasnain, A. Rehman and R. Perveen. 2018. Effect of botanical extracts: A potential biocontrol agent for Xanthomonas oryzae Pv. Oryzae, causing bacterial leaf blight disease of rice. Pakistan Journal of Agricultural Research, 32(1): 59-72.

DOI | http://dx.doi.org/10.17582/journal.pjar/2019/32.1.59.72

Keywords | Aqueous extracts, Antibacterial potential, Oryza sativa, Xanthomonas oryzae

\section{Introduction}

$\mathrm{R}$ ice (Oryza sativa L.) is one of the most important and widely cultivated cereal crops all over the world (Salim et al., 2003). The tropical and subtropical areas of the world are the major rice producer while $90 \%$ of the total rice production is occurring in Asian countries (Ezuka and Kaku, 2000). Heavy losses due to rice pests and diseases are the major constraints in world rice production. This important crop badly suffers from more than forty different microbial disease and disorders. Among them, bacterial leaf blight of rice (BLB) caused by Xanthomonas oryzae pv. oryzae (Swings et al., 1990) is a serious threat for irrigated, deep water, rainfed, temperate, tropical and subtropical rice growing areas of the world (Mew, 1987). This destructive disease has now become a serious pathosystem to rice crop especially in South East March 2019 | Volume 32 | Issue 1 | Page 59 
Asia. In Philippines, India, and Indonesia yield losses were noted $11-82 \%$ since the widespread cultivation of dwarf high yielding genotypes (Srivastava, 1967; Ou, 1985).

BLB is a vascular disease, symptoms appear at tillering stage which consisted of normally two phases i.e., kresek phase and leaf blight phase (Ou, 1985; Akhtar et al., 2008). The characteristic symptoms of disease are yellow lesions with typical wavy edges at the leaf blade, normally extend to sheath which later acquire whitish straw color (Mew and Majid, 1977). The devastating nature of disease can be noticed during the kresek phase when entire plant wilts, become pale yellow at the early tillering stage, resulting in total failure of the crop (Mew et al., 1993). BLB was first noticed in Pakistan at Rice Research Institute, Kala Shah Kaku on rice genotypes viz., Palman, IRRI-6 and Basmati 198 (Mew and Majid, 1977; Ahmad and Majid, 1980; Zafar et al., 2004). Akhtar and Akram (1987) described the potentials for BLB disease in Khyber PakhtunKhaw, Sindh and Punjab particularly in "Kallar belt" of the Punjab Province.

Use of plant products and biocontrol agents has been shown to be eco-friendly and effective against many plant pathogens. A number of plant species have been reported to possess natural sub-stances that are toxic to many fungi causing plant diseases (Susan et al., 2001). The excessive chemical use in rice production system has detrimental effects on the ecosystem especially on the beneficial predators and parasitoids (Brown et al., 1990). The medicinal and antimicrobial activities of many plants and their products have been known since the ancient times. These plant products are biologically active, easily biodegradable and relatively safe (Keifer et al., 1997; Saleem, 1988; Grange and Ahmed, 1988; Grayer and Harborne, 1994).

The antimicrobial activities of different botanicals against various plant diseases and foliar pathogens have been previously investigated (Okigbo and Nmeka, 2005; Akhter et al., 2008). Various secondary metabolites demonstrated the high degree of efficacy against the microbes e.g., saponified and unsaponified fractions of the green and brown seaweed, essential oil of botanicals, phenolics and flavanoids occurring in botanicals viz., Mentha piperita, Capsicum annum, Azadirachta indica, Citrus limon, Piper nigrum and Syzygium aromaticum, etc proved to be very effective against $X$. oryzae pv. oryzae and showed positive results (Sokmen et al., 2004; Ahmad et al., 2012). In most reports, however, efficacy of botanicals/ plant extracts has been evaluated only in vitro and supporting data for field trails are scarce. Evaluation of plant products against BLB disease in rice has been attempted earlier under both green-house and field conditions; however, no attempts have been made for the management of disease by using the mixtures of plant product to reduce the disease severity. The objectives of the present study are (1) to evaluate the antimicrobial activity of leaf extracts of various plant species against $X$. oryzae pv. oryzae under in vitro conditions, (2) to test effective plant extracts for suppression of BLB and their effect on agronomic traits in glass house and field.

\section{Materials and Methods}

The glass house and field experiments were carried out at the Agricultural Experimental Farms of Faculty of Agricultural Sciences and Technology, Bahauddin Zakariya University, $\left(30.268^{\circ} \mathrm{N}\right.$ and $71.495^{\circ} \mathrm{E}, 122$ $\mathrm{m}$ altitude from sea level), Multan, Pakistan. Planting material and experimental design.

The field and glass house experiments were conducted on three highly susceptible rice cultivars viz., Basmati super, IRRI-24 and TN-1 (Naqvi et al., 2015) obtained from National Agricultural Research Centre, Islamabad, Pakistan. For nursery preparation rice cultivars were sown on raised bed in a clayey loam soil covered with wheat straw and watered with shower thrice a day. After one week of sprouting the nursery was flooded with water. Meanwhile field having clayey loam soil was prepared for nursery transplantation. Forty days old rice seedlings were transplanted manually into the field. The completely randomized design was used for the experiment with each variety in a block and seven treatments viz., $M$. piperita, $O$. ficus indica, $A$. vera, $A$. indica, $A$. vera $+M$. piperita, O. ficus indica $+M$. piperita, $M$. piperita $+A$. indica $+C$. limon were randomized within the block. Each replication contains 15 plants that were shown at 9 inches' plant-plant and 9 inches' row-row distance in a square shape and there were two plants in each site. The crop was fertilized with N: P: K@ 140: 65: $60 \mathrm{Kg} /$ hectare. The experimental plots were irrigated daily for first 18 days and then on the demand of crop until its maturity. The normal cultural practices i.e., hoeing, weeding, insect pest sprays etc. were performed to maintain a healthy crop stand. Nursery 
for glass house experiment was prepared separately under control conditions and three rice plants were transplanted into each earthen pot. The completely randomized design (CRD) with three replicates was used for the experiment.

\section{In-vitro studies}

\section{Isolation of Xanthomonas oryzae pr. oryzae}

The diseased leaves were collected in sample bags from the field. Leaf tissues bits of $(0.5-1 \mathrm{~cm})$ were disinfected $1.00 \%$ sodium hypochlorite $(\mathrm{NaOCl})$ solution, rinsed thrice in double distilled water and later dried on sterilized blotter paper. These tissues were placed into sterilized petri plates containing Nutrient Agar (Bio Basic Inc. Canada) and kept at $27 \pm 1^{\circ} \mathrm{C}$ for $72 \mathrm{hrs}$. Bright yellow, viscous and circular colonies of the bacterium ( $X$. oryzae pv. oryzae) appeared in petri plates subsequently and purified (Wilson et al., 1967). Hypersensitivity reaction was performed and bacterium was identified by different biochemical tests (Naqvi et al., 2015).

\section{Preparation of botanical extracts}

Different parts (leave, fruit, seeds and bark) of fifteen plant species (Table 1) were collected from Multan, washed thoroughly under tap water thrice and dried completely under shade. The dried plant material was ground into a fine powder with a pestle and mortar except the Aloe vera and Opuntia ficus-indica which were extracted in aqueous paste form. Ten grams of fine ground powder were homogenized in $100 \mathrm{ml}$ of distilled water in a sterilized conical flask, shaken vigorously for $15 \mathrm{~min}$ and allowed to stand at room temperature for $6 \mathrm{hr}$, filtered through three layers of cheese cloth and then through sterilized What man No. 1 filter paper and finally water bath for 15 minutes (Meisner et al., 1986; Ahmad and Beig, 2001). The details of the tested botanicals used are given in (Table 1).

\section{Culture conditions and inoculums preparation}

Pathogen was isolated on nutrient agar and preserved in agar plates in a standard refrigerator at $4^{\circ} \mathrm{C}$ for optimal viability of bacterial colonies. Bacterial masses of $X$. oryzae pv. oryzae were collected by using a lab spatula from all the culture plates and added to distilled water in a conical flask. Inoculum concentration was adjusted to $10^{5} \mathrm{cfu} / \mathrm{ml}$ (for in vitro) with the optical density 0.7-1.3 using the spectrophotometer (UV 300 , ORI, Germany) at the wavelength of $600 \mathrm{~nm}$
(Naqvi et al., 2015).

\section{Poison food technique}

Poison food technique was used to determine the efficacy of the botanicals against $X$. oryzae pv. oryzae on nutrient agar poisoned with each tested plant extracts in three replicates (Devadath, 1970). The petri plates were poisoned at three different concentrations viz., 5, 25 and $50 \%(\mathrm{v} / \mathrm{v})$, with $100 \mu 1$ of each plant extract prior to pouring of media. Bacterial suspension of $100 \mu \mathrm{l} /$ plate was uniformly spread on medium with sterilized spreader to obtain well separated colonies of the bacteria. The inoculated petri plates were completely randomized and placed at $27 \pm 1^{\circ} \mathrm{C}$ in incubator for $72 \mathrm{hrs}$. The bacterial colonies were counted after 36 and $72 \mathrm{hrs}$.

\section{Disk diffusion technique}

Bacterial suspension was plated uniformly on the surface of each petri plate containing NA. Sterilized disks of $6 \mathrm{~mm}$ diameter of Whatman No. 1 filter paper were impregnated for 5 -to-10 seconds in three different concentrations viz., 5, 25 and $50 \%$ of each plant extract and placed on the surface of media on each petri plate. The petri plates were randomized and kept at $27 \pm 1^{\circ} \mathrm{C}$ in incubator. The inhibition zones were measured after 36 and $72 \mathrm{hrs}$ (Devadath, 1970).

\section{Field inoculation}

Bacterial concentration was adjusted to about $10^{8} \mathrm{cfu} /$ $\mathrm{ml}$ corresponds to optical density $0.7-1.3$ using the spectrophotometer (UV 300, ORI, Germany) at the wavelength of $600 \mathrm{~nm}$ for the successful inoculation in the field (Naqvi et al., 2015). The antibacterial activity of botanicals under the field conditions was determined on three highly susceptible varieties viz., Basmati super, IRRI-24, and TN-1 by clipping method wherein approximately $1-2 \mathrm{~cm}$ of leaf tip is cut with scissors or clippers previously dipped in bacterial suspension on the cutting edge (Kauffman et al., 1973). The inoculation was completed in the evening time to favor the entry of bacteria into infection courts in the presence of enough moisture on leaf surface. The best concentration of selected botanicals in the in-vitro evaluation were sprayed after 15 days of interval on 630 plants of three susceptible varieties to find out their efficacy in controlling the disease severity of BLB of rice.

For the antibacterial activity of selected botanical extracts under glass house conditions, sixty days old plants of three varieties sown in earthen pots were inoculated using the clipping method with scissors. 
Table 1: List of plant parts (treatments) tested for the antibacterial activity against Xanthomonas oryzae pv. oryzae.

\begin{tabular}{|c|c|c|c|c|c|c|}
\hline Plant no. & Scientific name & Common name & Family & Part used & Active Ingredient & Reference \\
\hline 1 & Mentha Piperita & Mint & Labiatae & Leaves & Mentha & Iscan et al., 2002 \\
\hline 2 & Piper nigrum & Black peeper & Piperaceae & Fruit & Piperine & Ahmed et al., 2012 \\
\hline 3 & Capsicum annuum & Red Peeper & Solanaceae & Fruit & Capsicine & Ahuja \& Ball, 2006 \\
\hline 4 & Syzygium cumini & Jaman & Myrtaceae & Seed & Jambosine & Afify et al., 2011 \\
\hline 5 & Azadirachta indica & Neem & Meliaceae & Fruit & Azadirachtin & Kumar et al., 2010 \\
\hline 6 & Moringa oleifera & Sohangna & Moringaceae & Leaves & Moringine & Anwar et al., 2007 \\
\hline 7 & Citrus limon & Lemon & Rutaceae & Fruit & Naringenin & Bansode, 2012 \\
\hline 8 & Prosopis juliflora & Keekar & Fabaceae & Leaves & Flavonoids & Ibrahim et al., 2013 \\
\hline 9 & Syzygium aromaticum & Clove & Myrtaceae & Fruit & Eugenol & Debjit et al., 2012 \\
\hline 10 & Saraca Asoca & Aashoka & Fabaceae & Leaves & Catechin & Manas \& Nath, 2011 \\
\hline 11 & Curcuma longa & Haldi & Zingiberaceae & Fruit & Monoterpenes & Li et al., 2011 \\
\hline 12 & Mangifera indica & Mango & Anacardiaceae & Seed & Mangiferin & Zou et al., 2014 \\
\hline 13 & Cinnamomum zeylanicum & Dar Cheeni & Lauraceae & Bark & Cinnzeylaine & Priyanga et al., 2013 \\
\hline 14 & Aloe vera & Aloevera & Xanthorrhoeaceae & Leaves & Alkaloids & Patel et al., 2012 \\
\hline 15 & Opuntia ficus-indica & Cactus & Cactaceae & Leaves & Flavonoids & Dib et al., 2013 \\
\hline
\end{tabular}

The inoculation of 345 plants of three varieties having three replicates with five plants in each replication was done by creating high moisture level through spraying water on the plants before inoculation. The most effective concentration of in vitro experiment was selected to apply in the glass house and in field experiment. Four sprays of seven botanicals at 5, 25 and $50 \%$ concentration as determined under in-vitro were applied after 15 days' interval by sprayer during the morning times to check their potential against bacterial spread.

Assessment of disease severity and agronomic traits

Disease severity was recorded using the standard evaluation system of rice (IRRI, 1996). Disease severity of bacterial leaf blight was estimated using the formula (Anonymous, 1996) described below:

Disease severity index $=\frac{\text { Sum of all the score of Individual plants } / \text { variety }}{\text { Total No. of Plants Observed }} \times \frac{100}{\text { Maximum Scale }}$

Six agronomic traits of rice crop viz., plant height $(\mathrm{cm})$, number of tillers, panicle length $(\mathrm{cm})$, number of grains/ panicle, 500 grains weight $(\mathrm{g})$ and paddy yield ( $t / h a)$ were also determined by recording the data of respective traits.

\section{Statistical analysis}

The collected datasets were subjected to analysis of variance (ANOVA). All the treatments mean of total datasets were compared by the least significant difference (LSD) for the in vitro and glass house experiments and Duncan's Multiple Range (DMR) test for multiple mean comparison at $(P \leq 0.05)$ for field experiment by using the statistical software package (IBM SPSS, Statistics 21).

\section{Results and Discussion}

\section{In-vitro evaluation of antibacterial activity of various botanicals}

Poison food technique was found to be useful for the evaluation of botanical extracts. Only eight plant decoctions either singly or in combination viz., Mentha piperita, Piper nigrum, Azadirachta indica, Aloe vera, Aloe vera + Mentha piperita, Opuntia ficus indica + Mentha piperita, Moringa oleifera + Mentha piperita and the combination of Mentha piperita + Azadirachta indica + Citrus limon were found to have significant $(P \leq 0.05)$ antibacterial activity. The concentration of $50 \%$ of plant decoction showed the best results and a minimum average of $6.33(P \leq 0.05)$ bacterial colonies were counted (Figure 1). The diameter of inhibition zone was also measured during the in vitro experiment by the use of disk diffusion technique. Three plant decoctions i.e., $M$. piperita, $A$. indica and the combination of $M$. piperita $+A$. indica $+C$. limon showed highly significant response against the $X$. oryzae pv. oryzae and gave an average diameter of inhibition zone of 28.62, 25.04 and $26.22 \mathrm{~mm}$ respectively while $P$. nigrum, $C$. limon, Curcuma longa and Cinnamomum zeylanicum individually performed well against the tested bacterium. The highest concentration of botanicals extracts i.e., $50 \%$ showed the maximum diameter of inhibition zone (Figure 2). 


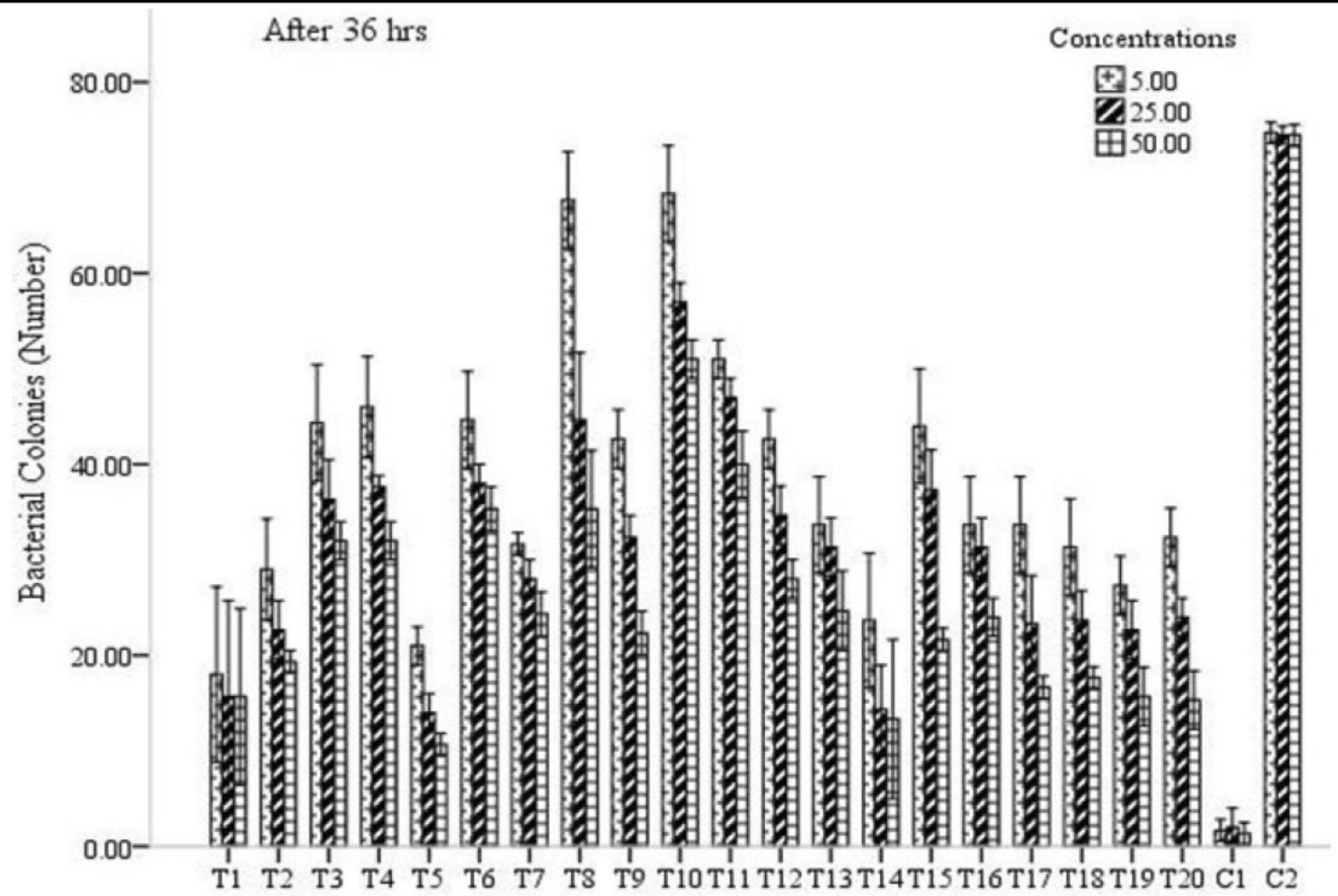

Treatments

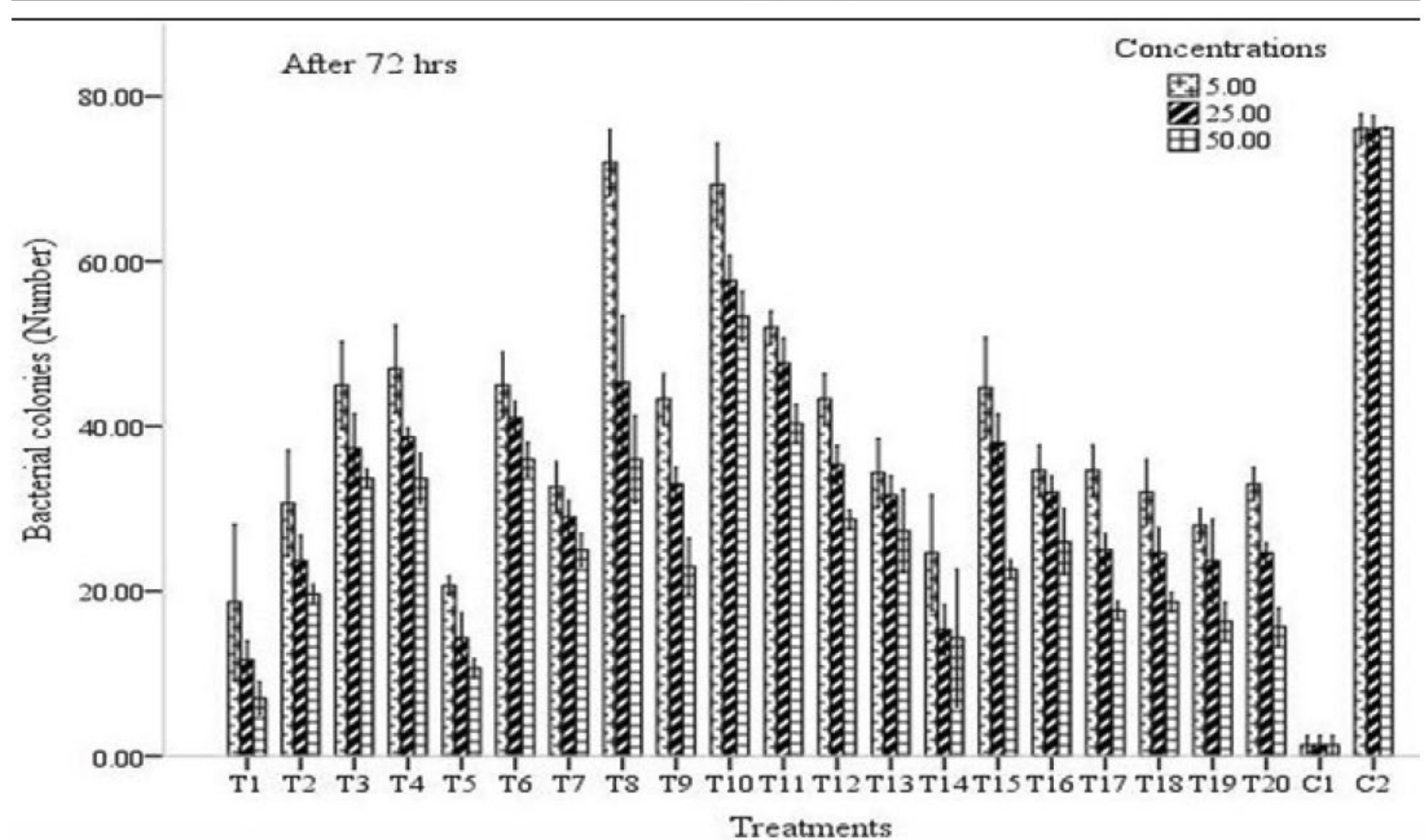

Figure 1: In vitro inbibition of Xanthomonas oryzae pv. oryzae on nutrient agar under the effect of various plant extracts by poison food technique. While T1, T2, T3, T4, T5, T6, T7, T8, T9, T10, T11, T12, T13, T14, T15, T16, T17, T18, T19, T20, C1, C2 shows Mentha Piperita, Piper nigrum, Capsicum annuum, Syzygium cumini, Azadiraehta indica, Moringa oleifera, Citrus limon, Prosopis juliflora, Syzygium aromaticum, Saraca Asoca, Curcuma longa, Mangifera indica, Cinnamomum zeylanicum, Aloe vera, Opuntia ficus-indica, Aloe vera + Opuntia ficus-indica, Aloe vera + Mentha Piperita, Opuntia ficus-indica + Mentha Piperita, Mentha Piperita + Azadiraehta indica + Citrus limon, Moringa oleifera + Mentha Piperita, and Control-ive (Water), Control +ive (Streptomycin).

\section{Glass house experiment}

Based on the efficacy of various botanical products to inhibit the growth of pathogen as determined in-vitro trials, we selected seven different botanicals extracts viz., $M$. piperita, O. ficus indica, Aloe vera, $A$. indica, Aloe vera $+M$. piperita, O. ficus indica $+M$. piperita, $M$. piperita $+A$. indica $+C$. limon were selected to test their efficacy against bacterial leaf blight disease 
severity under glass house conditions on basmati super, IRRI-24 and TN-1. The decoctions of M. piperita $+A$. indica + C. limon showed the highest efficacy with the average decrease of $9.14(P \leq 0.05)$ in disease severity followed by $A$. indica and $M$. piperita with 9.41 and 9.96 decrease in disease severity respectively. Similarly, on cultivar IRRI-24, plant decoctions of $A$. indica showed highest efficacy with the average decrease of 8.44 in BLB disease severity followed by the combination of $M$. piperita $+A$. indica $+C$. limon, which showed average decrease of 8.47 and $M$. piperita with 8.92 after the four sprays. Similar results were observed on cultivar TN-1, the decoctions of the combination of three botanicals viz., $M$. piperita $+A$. indica and C. limon showed higher efficacy with average decrease of 8.17 in the disease severity followed
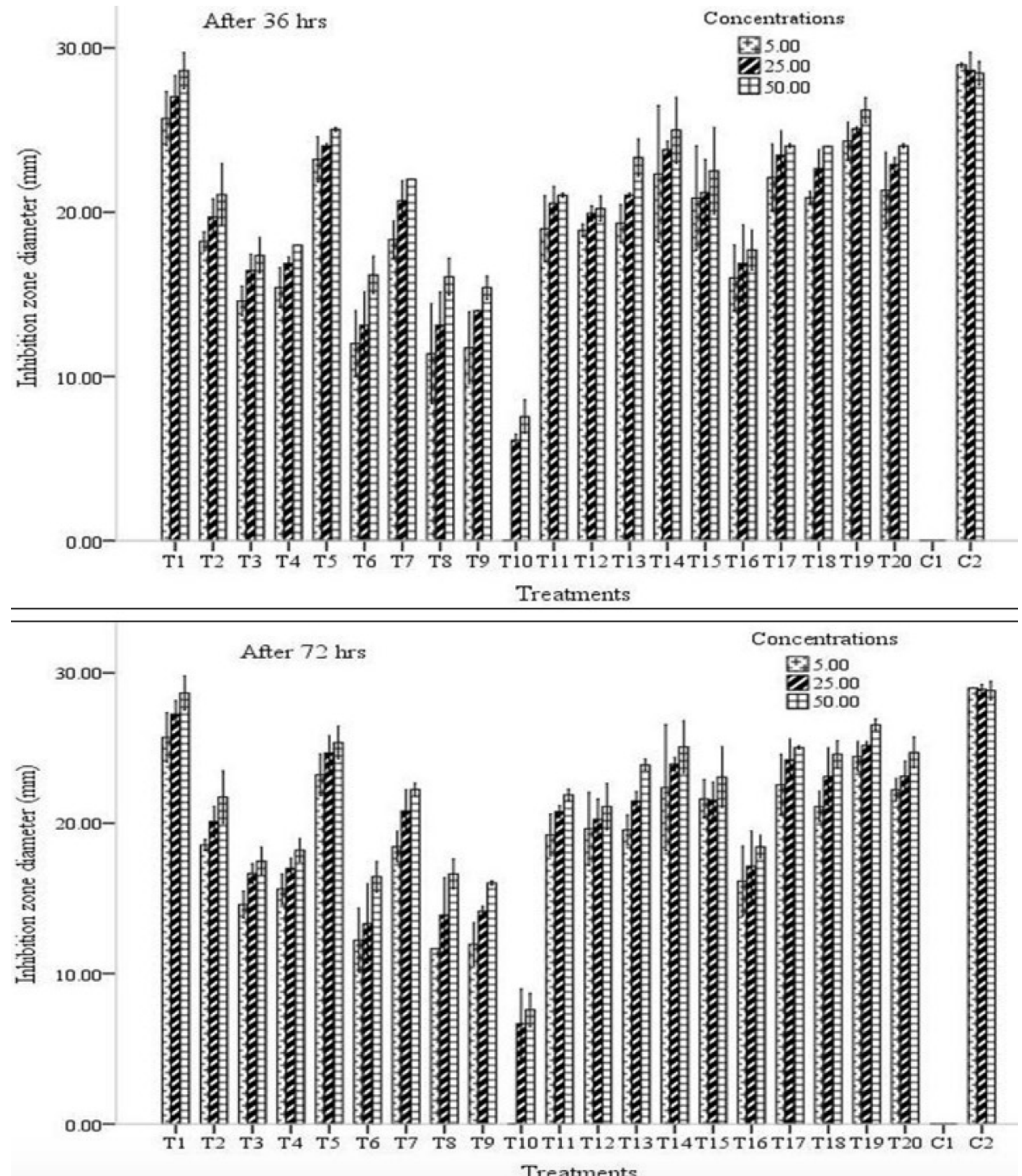

Figure 2: In vitro inbibition of Xanthomonas oryzae pv. oryzae on nutrient agar under the effect of various plant extracts by Disk diffusion technique. While T1, T2, T3, T4, T5, T6, T7, T8, T9, T10, T11, T12, T13, T14, T15, T16, T17, T18, T19, T20, C1 and C2, shows Mentha Piperita, Piper nigrum, Capsicum annuum, Syzygium cumini, Azadiraebta indica, Moringa oleifera, Citrus limon, Prosopis juliflora, Syzygium aromaticum, Saraca Asoca, Curcuma longa, Mangifera indica, Cinnamomum zeylanicum, Aloe vera, Opuntia ficus-indica, Aloe vera + Opuntia ficus-indica, Aloe vera + Mentha Piperita, Opuntia ficus-indica + Mentha Piperita, Mentha Piperita + Azadiraehta indica + Citrus limon, Moringa oleifera + Mentha Piperita, and Control-ive (Water), Control +ive (Streptomycin). 

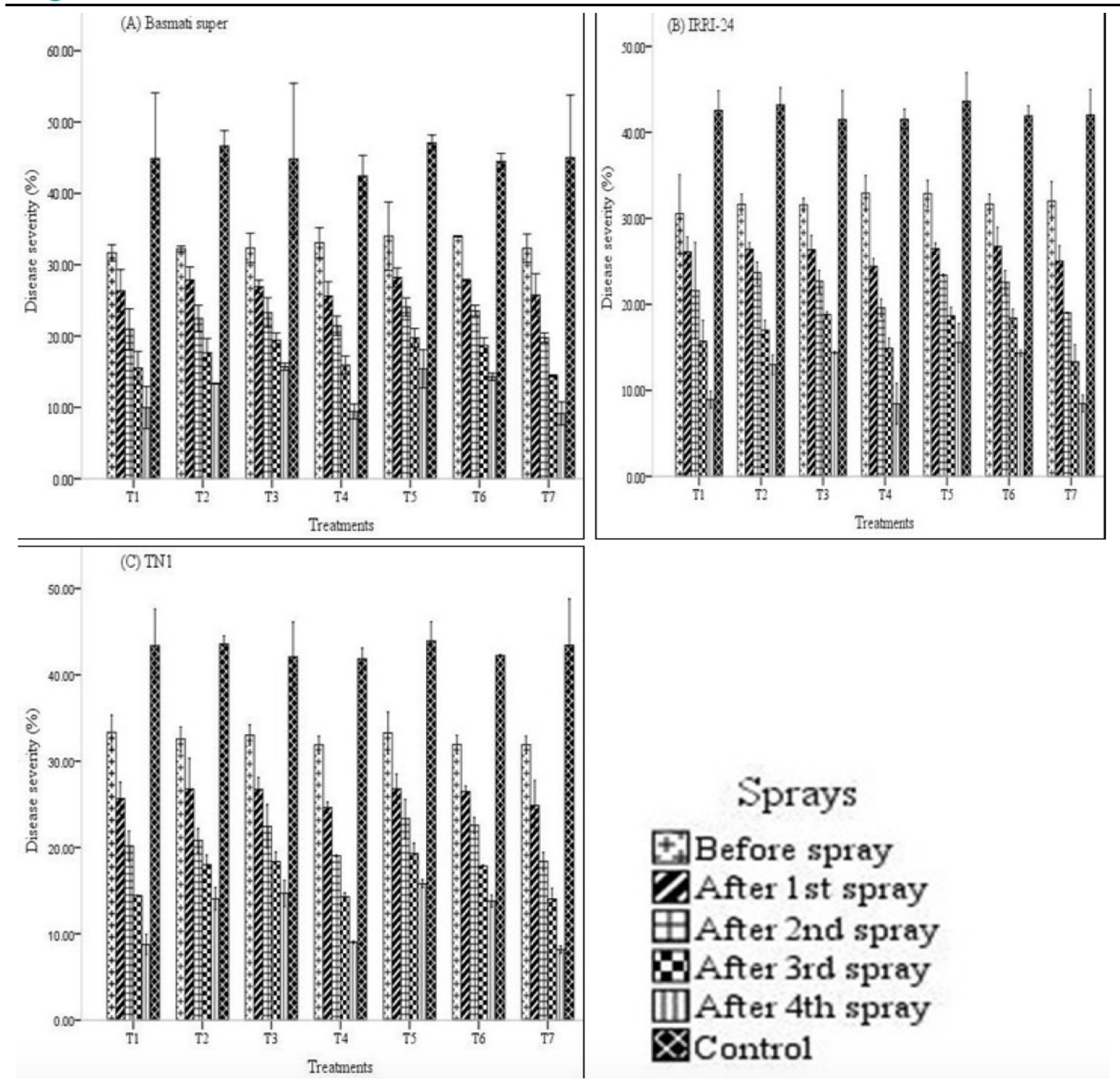

Figure 3: Effect of various botanicals singly or in combination with others for the suppression of bacterial leaf bight of rice in the green house on three highly susceptible cultivars. (A), Basmati super (B), IRRI-24 (C), TN1, while T1, T2, T3, T4, T5, T6 and T7 shows Mentha piperita, Opuntia ficus indica, Aloe vera, Azadirachta indica, Aloe vera + Mentha piperita, Opuntia ficus indica + Mentha piperita, Mentha piperita + Azadirachta indica + Citrus limon respectively. Wherein Control shows untreated plants.

by $M$. piperita with 8.77 and relatively less degree of efficacy was observed on this cultivar by $A$. indica with 9.04 decrease in disease severity (Figure 3 ).

\section{In-vivo experimentation}

The same seven plant decoctions ( $M$. piperita, $O$. ficus indica, $A$. vera, $A$. indica, $A$. vera $+M$. piperita, $O$. ficus indica $+M$. piperita, $M$. piperita $+A$. indica $+C$. limon) that were used in the glass house assay were evaluated for field assay on three varieties viz., Basmati super, IRRI-24 and TN-1. On Basmati super all the treatments gave good response against BLB disease yet the combination of $M$. piperita $+A$. indica $+C$. limon showed highest efficacy for the disease control with $83.98 \%$ reduction in disease over control followed by $M$. piperita with $81.90 \%$ reduction in disease. Similarly, in case of IRRI-24, the combination of $M$. piperita $+A$. indica $+C$. limon revealed greater efficacy for disease control with $84.44 \%$ reduction in disease over control followed by $M$. piperita and $A$. indica which showed 83.81 and $82.21 \%$ reduction in disease over control. For TN-1, the same treatments 
showed greater efficacy for the disease control, the combination of three decoctions also performed well with the maximum reduction of $83.02 \%$ over control (Figure 4).

All the treatments showed significant effect on the measured agronomic traits of rice plants as compared to control at $(P \leq 0.05)$. Super basmati plants treated with $M$. piperita showed maximum $118.45 \mathrm{~cm}$ height as compared to control. There was significant effect of all the treatments on the number of tillers of IRR124 as compared to control with maximum tillering on the treatment $M$. piperita and $M$. piperita $+A$. indica + C. limon with 21 and 22 tillers respectively. Similarly, the panicle length of variety basmati super showed significant effect of treatment $M$. piperita, $A$. indica and $M$. piperita $+A$. indica $+C$. limon as compared to control with 28.05 and $28.34 \mathrm{~cm}$ respectively. IRRI24 appeared to be significantly responsive in case of no of grains/panicle under the effect of $M$. piperita as compared to control with 124.33 grains. Treatments $M$. piperita and $M$. piperita $+A$. indica $+C$. limon showed significant effect on weight of grains (500g) of variety IRRI-24 as compared to control whereas maximum weight was recorded $15.99 \mathrm{~g}$ and $15.67 \mathrm{~g}$ respectively. The paddy yield was calculated in tonnes/ hac and the variety IRRI-24 showed significant yield as compared to other varieties under the effect of various treatments. The most effective treatments were $M$. piperita and $M$. piperita $+A$. indica $+C$. limon which gave maximum yield 6.66 and $6.33 \mathrm{~g}$ respectively (Figure 5) (Table 2).


Figure 4: Effect of various botanicals singly or in combination with others for the suppression of bacterial leaf bight of rice in the field on three highly susceptible cultivars. (A), Basmati super (B), IRRI-24 (C), TN1, while T1, T2, T3, T4, T5, T6 and T7 shows Mentha piperita, Opuntia ficus indica, Aloe vera, Azadirachta indica, Aloe vera + Mentha piperita, Opuntia ficus indica + Mentha piperita, Mentha piperita + Azadirachta indica + Citrus limon respectively. Wherein Control 1 (Inoculated + Treated with streptomycin), Control 2 (Inoculated + Water) and Control 3 are (Uninoculated + Untreated).

March 2019 | Volume 32 | Issue 1 | Page 66 
$150.00-$


$150.00-$
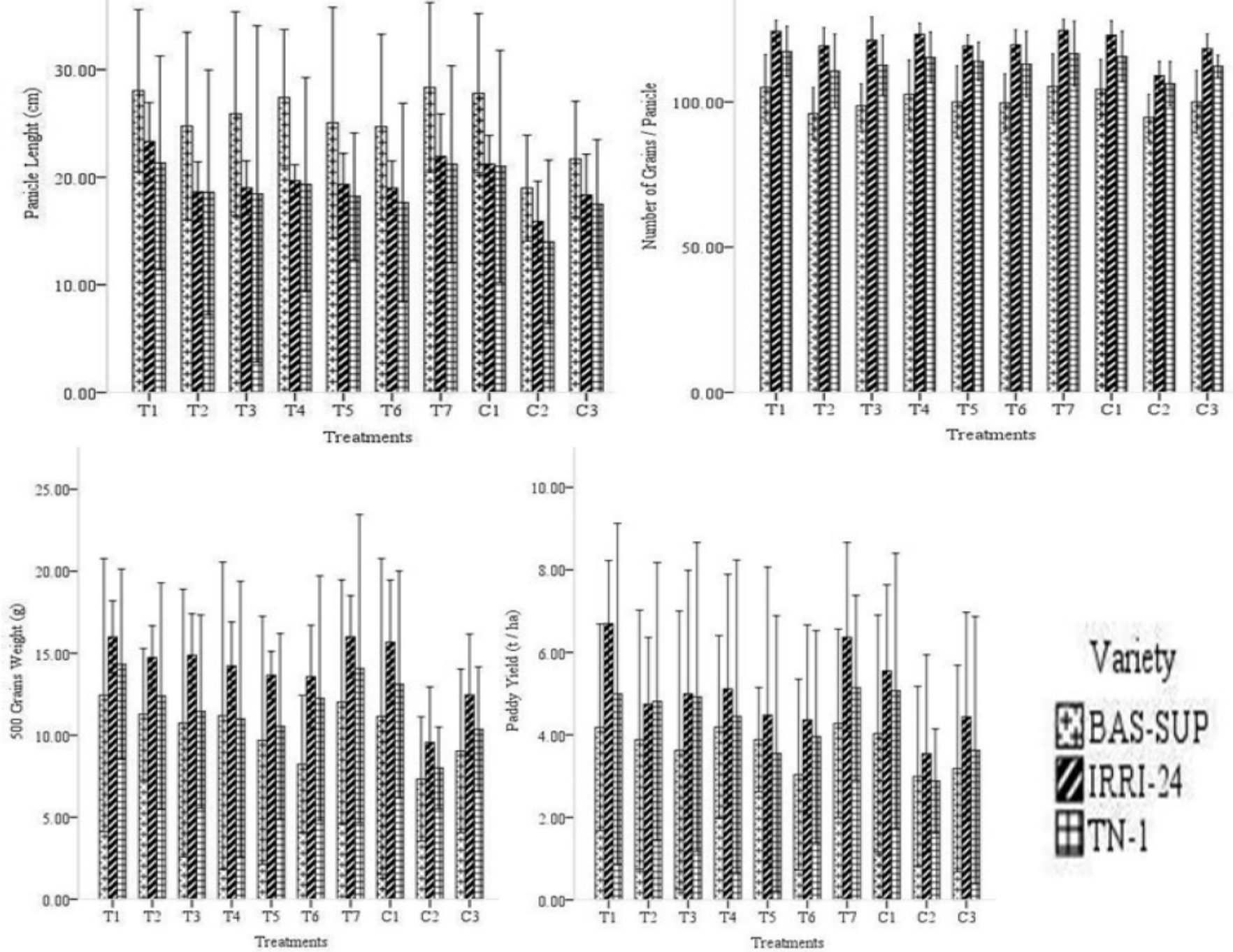

Figure 5: Yield data of three rice cultivars under the effect of various treatments viz., T1, T2, T3, T4, T5, T6, T7, CI, C2 and C3 showing Mentha Piperita, Opuntia ficus-indica, Aloe vera, Azadiraehta indica, Aloe vera + Mentha Piperita, Opuntia ficus-indica + Mentha Piperita, Mentha Piperita + Azadiraehta indica + Citrus limon respectively whereas C1 (Inoculated + Treated with streptomycin), C2 (Inoculated + Treated with Water) and C3 (Uninoculated + Untreated) respectively. $A=$ Plant height, $B=$ No of tillers, $C=$ Panicle length, $D=$ No of grains/ panicle, $E=500$ grains weight in grams and $F=$ Paddy yield ( $t / h a)$ respectively.

Biological control strategy using plant extracts is Previous studies have exposed several plant extracts considered environment friendly and cost effective. to effectively reduce the pathogen inoculums and March 2019 | Volume 32 | Issue 1 | Page 67 
increase symptomless plant stand in the controlled as well as natural conditions (John and James, 1999). Under both conditions, we were able to determine either any of the plant extracts was effective and deserving further research. The results of our study showed seven plant extracts viz., $M$. piperita, $P$. nigrum, $A$. indica, $A$. vera, $A$. vera $+M$. piperita, $O$. ficus indica $+M$. piperita, Moringa oleifera $+M$. piperita and the combination of $M$. piperita $+A$. indica $+C$. limon were found to have appreciable antibacterial activity when used either singly or in combination with another plant extract produced significant effect against the disease under in-vitro conditions. We observed that at $50 \%$ concentration of plant extract revealed the best results and a minimum average of 6.33 bacterial colonies were counted. Similarly, the zone of inhibition was also measured during the in-vitro experiment by the disk diffusion technique and our results showed three plant extracts i.e., $M$. piperita, $A$. indica and the combination of $M$. piperita $+A$. indica $+C$. limon to produce highly significant response against the $X$. oryzae pv. oryzae and gave an average inhibition zone of 28.62,25.04 and $26.22 \mathrm{~mm}$ respectively while $P$. nigrum, $C$. limon, $C$. longa and $C$. zeylanicum individually performed well against the tested bacterium. In this technique the highest concentration of botanical extracts i.e. 50\% again showed the maximum diameter of inhibition zone.

Table 2: Effect of botanicals for the percent reduction of bacterial leaf blight of rice in field.

\begin{tabular}{|c|c|c|c|}
\hline Treatments & Percent reduct & tion over $c$ & control \\
\hline & Basmati super & IRRI-24 & TN1 \\
\hline Mentha Piperita & 81.90 & 83.81 & 82.36 \\
\hline Opuntia ficus-indica & 78.15 & 76.65 & 73.15 \\
\hline Aloe vera & 76.61 & 78.67 & 72.48 \\
\hline Azadiraehta indica & 78.84 & 82.21 & 80.83 \\
\hline Aloe vera + Mentha Piperita & 80.29 & 78.12 & 76.64 \\
\hline $\begin{array}{l}\text { Opuntia ficus-indica }+ \text { Men- } \\
\text { tha Piperita }\end{array}$ & 79.33 & 77.14 & 70.12 \\
\hline $\begin{array}{l}\text { Mentha Piperita }+ \text { Azadirae- } \\
\text { bta indica + Citrus limon }\end{array}$ & 83.98 & 84.44 & 83.02 \\
\hline $\begin{array}{l}\text { Control (Inoculated + treat- } \\
\text { ed with streptomycin) }\end{array}$ & 89.33 & 88.59 & 87.85 \\
\hline
\end{tabular}

During the current study, seven plant extracts which performed exceptionally under the in-vitro conditions against the disease, were selected to evaluate under the natural environmental conditions i.e., in the field against the highly susceptible rice varieties.
Our findings of the field experiment showed that all the plants extracts performed significantly well individually yet the combination of $M$. piperita $+A$. indica showed higher efficacy for disease control with $83.98 \%$ reduction in disease over control followed by M.piperita which showed $81.96 \%$ reduction in disease over control. Our results are in accordance with Kagale et al. (2004) who studied the application of leaf extracts of $A$. indica on the plant surface prior to infection enforces resistance by inducing the production of secondary metabolites in the treated plants which suppressed not only the invasion of the pathogen but also promoted the vigor of the plant under glass house and field conditions effectively. Similarly, our results also coincide with Jabeen (2011) who reported several plant decoctions of the $A$. indica, $C$. longa, $C$. limon and $S$. aromaticum to effectively control the bacterial leaf blight disease severity under glass house and in field conditions. Similar studies were performed by Govindappa et al. (2011) and Afify et al. (2011) who studied the efficacy of three plant extracts for the management of $X$. oryzae pv. oryzae under in-vitro and glass house conditions and reported that all the tested decoctions significantly controlled the BLB pathogen, showing a greater antibacterial potential of $A$. indica. Our results are also supported by the findings of Leksomboon et al. (2001) who evaluated twenty-five different plant extracts against the two bacterial pathogens viz., $X$. compaestris oryzae pv. oryzae and Erwinia carovotaora, at the rate of varying concentrations under in vitro experiment and results showed $A$. indica and $C$. limon to perform well against the tested bacterium. Several lines of evidence from present study indicated that induced resistance might be a mechanism by which aqueous extracts resist disease evidenced by marked changes in the plant growth and yield response of rice plants. These might contribute to reduce disease severity by delaying lesion development thus suppressing the disease on treated rice plants using various plant extracts.

Besides this, our results are not in accordance with Narasimhan et al. (1995) who studied the in-vitro efficacy of different plant decoctions against the $X$. oryzae pv. oryzae and reported the diffusate of Piper nigrum showed the best efficiency against the tested bacteria while in our experiment mentioned diffusates failed badly to control the disease in-vitro and did not produce significant results. Our results do not support the findings of Kavitha and Satish (2011) who tested nine medicinal plants for their antimicrobial activity 
against important plant pathogenic bacteria such that $X$. compastresis pv. vesicatoria, $X$. axonopodis pv. malvicaerium, $X$. oryzae pv. oryzae and $E$. cartovora, results showed extracts of Emblica oficsenalis, Accacia nilotica and Carum copticum significantly controlled the bacterial growth under in-vitro and in-vivo conditions.

The differences between our findings and theirs may be due to the in-vivo nature of our experiment. When we analyzed our results, we observe that the extracts used in combination with another found to be more effective than the extracts used as single under invitro and in field experiments. Generally speaking, $M$. piperita having the active ingredient menthol (Iscan et al., 2002) when used either individually or in combination with other decoctions showed higher antibacterial activity against the tested disease. Likewise, $A$. indica having the active ingredient azadirachtin (Kumar et al., 2010) also showed greater efficacy for the control of the disease under both conditions.

In our experiments, we observed clearly that all the decoctions used under in-vitro conditions showed a greater efficacy for the control of disease as compared to the in-vivo conditions, perhaps it may be due to the controlled environmental and incubation conditions that were definitely not possible to provide in the field assays. Plant extracts and biocontrol agents induced host resistance through increased activity of enzymes such as peroxidase and polyphenol oxidase which play vital roles against invading pathogens (Ibrahim et al., 2013). The prospect of broad-spectrum disease control using the plant's own resistance mechanisms has led to increasing interest in the development of agents which can mimic natural inducers of resistance. Induction of systemic resistance can lead to the direct activation of defense-related genes, but also can lead to the priming of cells, resulting in stronger elicitation of those defenses or, indeed, other defenses following pathogen attack. The facts of our studies showed that the active compounds of the plant decoctions directly act on the pathogen and may induce the resistance of the experimental plants which in turn reduces the disease development while it was also an observation during the research that the effect of a plant decoction on the target pathogen population over time is an issue when determining whether repeated treatment application is necessary throughout the growing season or not. It may be suggested that consideration will need to be given to the mechanism of interaction of the decoction with the pathogen population on the host plant as described by John and James (1999). However, more work is the need of time on effective management of bacterial leaf blight of rice by plant extracts regarding their concentration and development into bio pesticides.

It is to be suggested that results of the in-vitro trial might be different with the in-vivo because some plant extracts possess only volatile components which interact with the pathogen while other compounds may inhibit the pathogen population when in direct contact with that target pathogen. The effect of all the treatments on yield parameters i.e., plant height $(\mathrm{cm})$, panicle length $(\mathrm{cm})$, number of tillers, number of grains / panicle, 500 grains weight $(\mathrm{g})$ and paddy yield ( $t /$ ha) showed significant effect as compared to control where only water was used. In our research, IR-24 appeared more responsive for all the agronomic traits as compared to the other two varieties i.e., basmati super and $\mathrm{TN}-1$. The most pronounced effect of the treatments was observed in number of tillers, panicle length, $500 \mathrm{~g}$ grains weight and paddy yield ( $\mathrm{t} /$ ha) whereas treatments $M$. pipperita and $M$. piperita + $A$. indica $+C$. limon appeared to be most effective on all the agronomic traits. Our findings are also in line with Ahmad and Beig (2001) who observed treatment of various plant extracts on seed germination and growth of cereal crop plants. Therefore, further research in this field has the potential to extend the usefulness of the natural plant products in crop production systems. During the current research, we observed that the plant extracts may also effect on the growth and vigor of the plant under the pathogen attack. We observed that in the beginning of the experiment disease severity index was high but after each spray the disease severity index decreased gradually. It does not mean that pathogen after infection eliminated and plants were cured and thus the disease severity index decreased. The decoctions inhibited the growth of the pathogen and at the same time the plant grew fast even under the stress of the disease. Therefore, the area of plants increased and thus ultimately disease severity index decreased. It was also our observation that the rice crop became lush green after every spray of plant decoctions. Further investigations are needed to establish which bioactive constituents are involved in the induction of resistance in rice against bacterial leaf blight of rice. 
The study demonstrated that in addition to direct control of pathogens, plant extracts represented an ecofriendly alternative to chemical pesticides for systemic protection against pathogens. A major advantage of plant extracts is that not only it suppresses the growth of pathogen but also promote the healthy crop stand in the field. Therefore, certainly plant extracts represent a potentially valuable crop protection tool in high-value cropping systems like cereals where the high use of chemicals leads to contamination.

\section{Acknowledgements}

The study was funded by the Directorate of Research and External Linkages, Bahauddin Zakariya University, Multan. This manuscript is a part of $\mathrm{M}$. Phil. thesis of Syed Atif Hasan Naqvi, submitted to Department of Plant Pathology, Bahauddin Zakariya University, Multan.

\section{Author's contribution}

Syed Atif Hasan Naqui, Rashida Perveen, Ummad ud Din Umar and Ateeq ur Rehman conceived the idea. The experiments were performed by Syed Atif Hasan Naqvi and write up was also made up by Syed Atif Hasan Naqvi while SPSS analysis was performed by Syed Atif Hasan Naqvi and Ammarah Hasnain.

\section{References}

Afify, A.E.M., S.A. Fayed, E.A. Shalaby and H.A. Shemy. 2011. Syzygium cumini (Pomposia) active ingredient exhibit potent anticancer and antioxidant activities. Afr. J. Pharm. Pharmacol. 5: 948-956.

Ahmad, W. and A. Majid. 1980. Incidence of bacterial blight of rice in the Punjab, Pakistan. IRRN. 5: 5.

Ahmad, I. and A.Z. Beig. 2001. Antimicrobial and phytochemical studies on 45 Indian medicinal plants against multidrug resistant human pathogens. J. Ethnopharmacol. 74: 113-123. https://doi.org/10.1016/S03788741(00)00335-4

Ahmad, N., H. Fazal, B.H. Abbasi, S. Farooq, M.
Ali and M.A. Khan. 2012. Piper nigrum L. (Black Pepper): A review. Asian Pac. J. Trop Biomed. S: 1945- 1953.

Ahuja, K.D. and M.J. Ball. 2006. Effects of daily ingestion of chilli on serum lipoprotein oxidation in adult men and women. Br. J. Nutr. 96: 239242. https://doi.org/10.1079/BJN20061788

Akhtar, M.A. and M. Akram. 1987. Incidence of bacterial blight of rice in the Punjab (Pakistan). Int. Rice Res. Newsl. 5: 5.

Akhtar, M.A., A. Rafi and A. Hameed. 2008. Comparison of methods of inoculation of Xanthomonas oryzae pv. oryzae in rice cultivars. Pak. J. Bot. 40: 2171-2175.

Anonymous. 1996. Standard evaluation system for Rice. Int. Rice Test. Prog. Int. Rice. Res. Inst. Philipp.

Anwar, F., S. Latif, M. Ashraf and A.H. Gillani. 2007. Moringa olifera: A food plant with multiple medicinal uses. Rev. Artic. Phytopathol. Res. 21: 17-25.

Bansode, D.S. and M.D. Chawan. 2012. Studies on antimicrobial activity and phytochemical analysis of citrus fruit juices against selected pathogens. Int. Res. J. Pharm. 11: 122-126.

Brown, L.M., A. Blair, R. Gibson, G.D. Everett, K.P. Cantor, L. M. Schuman, L.F. Burmeister, S.F. Van Lier and F. Dick. 1990. Pesticide exposures and other agricultural risk factors for leukemia among men in Iowa and Minnesota. Cancer Res. 50: 6585-6591.

Debjit, B., S. Kumar, A. Yadav, S. Srivastava, S. Paswan and A.S. Dutta. 2012. Recent trends in Indian traditional herbs Syzygium aromaticum and its health benefits.J.Pharmocol.Phytochem. 1: 13-22.

Devadath, S. 1970. Screening of antibiotics and chemicals against bacterial blight of rice. Oryza. 7: 33-38

Dib, H., M.C. Beghdad and M. Belarbi. 2013. Phytochemical study of Algerian Opunita ficus indica. Ann. Biol. Res. 4: 185-189.

Devadath, S. and A.P. Dath. 1970. Screening of antibiotics and chemicals against bacterial blight of rice. Oryza. 7: 33-38.

Ezuka, A. and H. Kaku. 2000. A historical review of bacterial blight of rice. Nat. Inst. Agrobiol. Resour. Bull. Jpn. p. 207.

Grange, M. and S. Ahmed. 1988. Handbook of plants with pest control properties. John Wiley and sons, New York. 
Grayer, R.J. and J.B. Harborne. 1994. A survey of antifungal compounds from higher plants, 1982-1993. Phytochem. 37: 19-42. https://doi. org/10.1016/0031-9422(94)85005-4

Govindappa, M., S. Umesha and S. Lokesh. 2011. Adathoda vasica leaf extacts induces resistance in rice against bacterial leaf blight disease (Xanthomonas oryzae pv. oryzae). Int. J. P1. Physiol. Biochem. 3: 7-14.

Ibrahim, M., M. Nadir, A. Ali, V.U. Ahmed and M. Rasheed. 2013. Phytochemical analysis of Prosopis juliflora, SWARTZ DC. Pak. J. Bot. 45: 2101-2104.

IRRI. 1996. Standard evaluation and utilization system for rice 1996. IRRI publisher. PO Box, 933. Manila Philipp.

Iscan, G., N. Kirimer and M. Kurkcuoglu. 2002. Antimicrobial screening of Mentha piperita essential oils. J. Agric. Food Chem. 50: 39-43. https://doi.org/10.1021/jf011476k

Jabeen, R. 2011. Medicinal plants- A potential antibacterial source against bacterial leaf blight (BLB) of rice. Pak. J. Bot. 43: 111-118.

John, H.B. and C.L.James. 1999. Effect of botanical extracts on the population density of Fusarium oxysporum in soil and control of fusarium wilt in the greenhouse. Plant Dis. 84: 301-305.

Kauffman, H.E., A.P.K. Reddy, S.P.Y. Hsieh and S.D. Merca. 1973. An improved technique for evaluating resistance of rice varieties to Xanthomonas oryzae. Plant Dis. 57: 537- 541.

Kavitha, H.U. and S. Satish. 2011. Eco-friendly management of palnt pathogens by some medicinal plant extracts. J. Agric. Tech. 7: 449461.

Keifer, M.C. and R.K. Mahurin. 1997. Chronic neurologic effects of pesticide overexposure. Occup. Med. 12: 291-304.

Kagale, S., T. Marimuthu, B. Thayumanavan, R. Nandakumar and R. Samiyappan. 2004. Antimicrobial activity and induction of systemic resistance in rice by leaf extracts of Datura metel against Rhizoctonia and Xanthomonas oryzae pv. oryzae. Physiol. Mol. Plant Path. 65: 91-100. https://doi.org/10.1016/j.pmpp.2004.11.008

Kumar, P.S., D. Mishra, G. Ghosh and C.S. Panda. 2010. Biological action and medicinal properties of various constituent of Azadirachta indica (Meliaceae)" an Overview. Ann. Biol. Res. 3: 24-34.

Leksomboon, C., N.Thaveechai and W. Kositratana.
2001. Potential of plant extracts for control citrus canker of lime. Kaset J. Ntr. Sci. 35: 392396.

Li, S., W. Yuan, G. Deng, P. Wang, P.Yang and B.B. Aggarwal. 2011. Chemical composition and product quality control of turmeric (Curcuma longa L.) Pharma Crop. 2: 28-54. https://doi. org/10.2174/2210290601102010028

Manas, K.M. and D. Nath. 2011. Phytochemical screening and toxicity study of Saraca asoca bark methanolic extracts. Int. J. Phytomedic. 3: 498505.

Mew, T.W. and A. Majid. 1977. Bacterial blight of rice in Pakistan. Int. Rice Res. Inst. Newsl. 2: 5.

Meisner, J., S. Yathom, S. Tal and K.R.S. Ascher. 1986. The effect of various extracts of neem seed kernel on Liriomyza trifolii (Burgess). Diptera: pp. 288-89.

Mew, T.W. 1987. Current status and future prospects of research on bacterial blight of rice. Ann. Rev. Phytopathol. 25: 359-382. https:// doi.org/10.1146/annurev. py.25.090187.002043

Mew, T.W., A.M. Alvarez, J.E. Leach and J. Swings. 1993. Focus on bacterial blight of rice. Plant Dis. 77: 5-12. https://doi.org/10.1094/PD-770005

Naqvi, S.A.H., R. Perveen and S. Chohan. 2015. Evaluation of virulence of Xanthomonas oryzae pv. oryzae against rice genotypes. Int. J. Agric. Biol. 17: 166-175.

Narasimhan, V., R. Selvam and V. Mariappan. 1995. In: Mariappan V, editor. Neem for the management of crop diseases. New Delhi: Assoc. Publ. Co. pp. 15-121.

Okigbo, R.N. and I.A. Nmeka. 2005. Control of yam tuber rot with leaf extracts of Xylopia aethiopica and Zingiber officinale. Afr. J. Biotechnol. 4: 804-807.

$\mathrm{Ou}$, S.H. 1985. Rice diseases. 2nd edition. Commonwealth mycological institute. Kew, Surrey, Engl. pp. 61-96.

Patel, D.K., K. Patel and S.P. Dhanabal. 2012. Phytochemical standardization of Aloe vera extracts by HPLC technique. J. Acute Dis. 7: 47-50. https://doi.org/10.1016/S22216189(13)60011-6

Priyanga, R., A. Pigera, S. Sirimal, P. Galappathy, R.C. Godwin and K. Parsad. 2013. Medicinal properties of true cinnamon (Cinnamomum zeylanicum): A systemic review. BMC Compl. Altern. Med. 13: 275-285. https://doi. 
org/10.1186/1472-6882-13-275

Srivastava, D.N. 1967. Epidemiology and control of bacterial blight of rice in India. Proceedings of rice diseases and their control by growing resistant varieties and other measures. pp. 1118. Agric. For. Fish. Res. Counc.

Saleem, A. 1988. Use of neem and other botanical products for the control of nematodes and fungi infesting banana and other crops. A review. National seminar on banana and its problems in Sind, held on July 11-13, Hyderabad, Pakistan.

Swings, J., M. Mooter, V.D. Vauterin, L. Hoste, B. Gillis, T.W. Mew and K. Kersters. 1990. Reclassification of the causal agents of bacterial blight (Xanthomonas campestris pv.oryzae) and bacterial leaf streak (Xanthornonas campestris pv. oryzicola) of rice as pathovars of Xanthomonas oryzae (ex Ishiyama 1922) sp. nov. nom. rev. Int. J. Sys. Microbiol. 40: 309-311.

Susan, L., S.L. Schantz, D.M. Gasior, E. Polverejan, R.J. McCaffrey, A.M. Sweeney, H.E.B. Humphrey and J.C. Gardiner. 2001. Impairments of memory and learning in older adults exposed topolychlorinated biphenyls via consumption of Great Lakes fish. Environ.
Health Persp. 109: 605-611. https://doi. org/10.1289/ehp.01109605

Salim, M., M. Akram, M. Akhtar and M. Ashraf. 2003. Rice-A production hand book. Pak. Agric. Res. Cncl. p. 70.

Sokmen,A., M. Gulluce,H.A.Akpulat,D.Daferera, B. Tepe, M. Polissiou, M. Sokmen and F. Sahin. 2004. The in vitro antimicrobial and antioxidant activities of the essential oils and methanol extracts of endemic Thymus spathulifolius. Food Control. 15: 627-634. https://doi. org/10.1016/j.foodcont.2003.10.005

Wilson, E.E., P.M. Zeitoun and F.M. Fredrickson. 1967. Bacterial phloem canker, a new disease of Persian walnut trees. Phytopathol. 57: 618-621.

Zafar, N., S. Aziz and S. Masood. 2004. Phenotypic divergence for agro-morphological traits among landrace genotypes of rice (Oryza sativa L.) from Pakistan. Int. J. Agric. Biol. 2: 335-339.

Zou,T.B., E.Q.Xia,T.P.He,M.Y.Huang, Q.Jia and H.W. Li. 2014. Ultra sound assisted extraction of mangifera (Mangifera indica L.) leaves using response surface methodology. Molecules. 19: 1411-1421. https://doi.org/10.3390/ molecules19021411 